\title{
“Ruang Refleksi": Insight dari Program Pendampingan Sebaya Daring di Masa Pandemi COVID-19
}

\author{
SYURAWASTI MUHIDDIN*, AFGA YUDISTIKHAR, AZMUL FUADY IDHAM, SITTI MUTHIA MAGHFIRAH \\ MASSINAI, SYARIFA NADHRAH MUSTAMIN, \& GRISELDA MARIA ANCELA WODONG \\ Halo Jiwa Indonesia
}

\begin{abstract}
ABSTRAK
Laporan ini bertujuan untuk memberikan gambaran mengenai kegiatan Ruang Refleksi Online (RR0), sebuah program pendampingan sebaya yang diselenggarakan oleh Halo Jiwa Indonesia yang menyasar remaja dan dewasa muda, khususnya di masa pandemi Coronavirus Disease-19 (COVID-19). Melalui program ini, prinsip konseling sebaya daring dan Psychological First Aid (PFA) berupaya dipadukan. Hasil analisis menunjukkan bahwa kecenderungan persoalan yang dialami partisipan tergolong masalah personal, khususnya manajemen diri dan kecemasan. Terkait dengan efek pendampingan, partisipan melaporkan perasaan positif, seperti kelegaan dan perasaan senang. Mayoritas partisipan juga memberikan penilaian memuaskan terhadap RRO, yang mana pelayanannya dinilai dapat membantu mereduksi stres yang dirasakan. Hasil dari laporan ini juga menyajikan sejumlah kekuatan, kelemahan, peluang, serta ancaman dari program RRO yang dapat menjadi pertimbangan untuk pengembangan program serupa yang menggunakan prinsip pendampingan sebaya, pertolongan pertama psikologis, dan pelayanan psikologis daring yang potensial di masa yang akan datang seiring dengan perkembangan teknologi informasi dan komunikasi.
\end{abstract}

Kata kunci: daring, Halo Jiwa, layanan psikologis, pendampingan sebaya, ruang refleksi

\begin{abstract}
This report aimed to provide an overview of the Ruang Reflection Online (RRO) outcomes, a peer assistance program organized by Halo Jiwa Indonesia targeting teenagers and young adults, especially during the COVID-19 Pandemic Period. Through this program, the principles of online peer counselling and Psychological First Aid (PFA) are sought to be combined. The result analysis indicated that most of the problems experienced by the participants were classified as personal problems, especially selfmanagement and anxiety. Regarding the effect, participants reported positive feelings, such as relief and feelings of pleasure. The majority of participants also gave a satisfactory evaluation of RRO, in which the services were appraised to help reduce the perceived stress. This report also presented several strengths, weaknesses, opportunities, and threats from the RRO program that can be considered for the development of a similar program applying the principles of peer counselling, psychological first aid, and online psychological services which have the potential in the future, along with the development of information and communication technology.
\end{abstract}

Keywords: Halo Jiwa, online, peer assistance, psychological service, ruang refleksi 
INSAN Jurnal Psikologi dan Kesehatan Mental, 2021, Vol. 6(2), 90-105, doi: 10.20473/jpkm.v6i22021.90-105

Dikirimkan: 1 November 2021 Diterima: 28 November 2021 Diterbitkan: 1 Desember 2021

Editor: Rizqy Amelia Zein

*Alamat korespondensi: Kampiri Timur, Kecamatan Pammana, Wajo, Sulawesi-Selatan 90971. Pos-el: syurawasti@gmail.com

Naskah ini merupakan naskah dengan akses terbuka dibawah ketentuan the Creative Common Attribution License (http://creativecommons.org/licenses/by/4.0), sehingga penggunaan, distribusi, reproduksi dalam media apapun atas artikel ini tidak dibatasi, selama sumber aslinya disitir dengan baik.

\section{PEN D A H U L U A N}

Dewasa ini, dunia dihadapkan pada ancaman kesehatan yaitu pandemi Coronavirus Disease-19 (COVID19), termasuk di Indonesia. Sebagai upaya pencegahan, pemerintah mengeluarkan kebijakan Pemberlakuan Pembatasan Kegiatan Masyarakat (PPKM) di berbagai level, yaitu berupa pembatasan aktivitas di luar dan penerapan protokol kesehatan yang ketat. Dalam situasi tersebut, aktivitas keseharian yang dipusatkan di rumah mengakibatkan perubahan pola kebiasaan hidup masyarakat, atau yang dikenal sebagai Adaptasi Kebiasaan Baru (AKB). Perubahan tersebut mempengaruhi berbagai aspek kehidupan, seperti ekonomi, sosial, pendidikan, kesehatan, dan psikologis. Dari segi psikologis, pandemi COVID-19 menimbulkan masalah kesehatan mental, seperti perasaan stres, gelisah, kebingungan, ketakutan, perasaan tidak berdaya, kecenderungan untuk bunuh diri, dan depresi (Brooks, dkk., 2020).

Individu yang mengalami gangguan psikologis sangat disarankan untuk mencari bantuan saat mengalami masalah kesehatan mental. Dalam konstruk psikologi, hal ini disebut sebagai help-seeking atau mencari bantuan. Mencari bantuan adalah upaya yang dilakukan individu untuk memperoleh bantuan pihak eksternal, dalam hal penanganan masalah psikologis (Rickwood \& Thomas, 2012). Pada situasi tersebut, individu biasanya akan mengakses layanan kesehatan mental. Salah satu bentuk pelayanan tersebut bersifat formal dan ditangani oleh profesional. Pelayanan formal dinilai dapat memberikan efek jangka panjang kepada masyarakat, karena bantuan psikologis diberikan oleh tenaga ahli atau profesional yang terlatih (Xu, dkk., 2018). Meskipun demikian, beberapa kenyataan yang terjadi di Indonesia menunjukkan kurangnya intensi masyarakat untuk mencari bantuan, padahal layanan kesehatan mental dalam bentuk formal sudah tersedia. Hal ini dapat terlihat salah satunya dari data Riset Kesehatan Dasar (RISKESDAS) (2019) yang menunjukkan bahwa hanya 9 persen masyarakat Indonesia dengan gangguan depresi yang mencari bantuan untuk mengatasi kesehatan mentalnya.

Terdapat beberapa faktor yang dapat menyebabkan seseorang tidak mencari bantuan formal. Sejumlah penelitian sebelumnya mengungkapkan bahwa salah satu penyebab kurangnya intensi masyarakat untuk mencari bantuan adalah stigma tentang kondisi kesehatan mental, yang mana terdapat kecenderungan pemberian label kepada orang yang mengakses layanan formal, sebagai individu dengan sakit mental (Cerully, dkk., 2018; Corrigan, 2004; Stanley, dkk., 2018). Selain itu, penelitian yang dilakukan oleh Rasyida (2019) menunjukkan adanya faktor lain yang mempengaruhi intensi masyarakat untuk mencari bantuan, yaitu kurangnya pengetahuan tentang layanan konseling yang baik dan adanya anggapan bahwa masalah yang dialami masih kurang serius, sehingga terdapat keraguan untuk mengakses layanan kesehatan mental formal. Faktor ekonomi dan usia juga mempengaruhi intensitas masyarakat dalam mencari bantuan. Manumba dan Hamid (2020) mengungkapkan bahwa individu yang berada di rentang usia 25-34 tahun lebih tinggi kemungkinannya untuk mencari bantuan 
pada layanan kesehatan mental formal, dibanding kelompok usia 18-24 tahun, dalam hal ini rentang usia remaja hingga dewasa awal.

Apabila ditinjau dari kebijakan AKB di Indonesia, kalangan remaja dan dewasa awal menjadi sasaran PJJ (Pembelajaran Jarak Jauh). Berdasarkan penelitian dari Fitria dan Ifdil (2020), terdapat 54 persen remaja menunjukkan tendensi tingkat kecemasan (anxiety) yang tergolong tinggi di masa pandemi COVID-19. Selain remaja, dampak psikologis pandemi juga ditunjukkan oleh kalangan mahasiswa. Penelitian dari Aziz, dkk. (2021) menemukan bahwa masalah kesehatan mental di masa pandemi paling banyak ditemui pada kalangan usia 19-20 tahun, yaitu sebesar 35 persen. Dalam penelitian tersebut juga ditemukan data yang menunjukkan tingginya kasus masalah kesehatan mental pada perempuan dibandingkan laki-laki yaitu sebesar 31 persen.

Meskipun demikian, kelompok usia remaja dan dewasa awal cenderung kurang mengakses layanan kesehatan mental formal. Sejumlah penelitian justru menunjukkan tendensi kelompok usia tersebut untuk mengakses layanan kesehatan mental nonformal, seperti peer counseling atau konseling sebaya. Konseling sebaya digambarkan sebagai pelayanan konsultasi atau fasilitas bercerita nonprofesional yang disediakan oleh seorang konselor sebaya, yang memiliki usia dan kedudukan setara dengan penerima layanan (Turner, 1995). Hasil studi dari Ridha (2019) menjelaskan bahwa siswa sekolah menengah atas (remaja akhir) lebih memilih untuk mengakses fasilitas konseling sebaya karena merasa lebih dekat dan nyaman dengan konselor sebaya, sehingga cenderung lebih terbuka dalam menceritakan persoalannya. Hal tersebut sejalan dengan peningkatan akses layanan BK, sejak adanya program konseling sebaya. Dalam konteks studi tersebut, konseling sebaya bertujuan untuk mendampingi siswa dalam menangani persoalan yang tergolong ringan hingga kategori sedang. Selain itu, dalam pengaplikasiannya, konselor sebaya adalah sejumlah siswa yang telah mengikuti pelatihan konseling sebaya oleh profesional. Sejalan dengan studi tersebut, penelitian dari Damayanti dan Wahida (2019) pada mahasiswa (dewasa awal) menemukan bahwa layanan konseling sebaya yang dikelola secara terencana dan sistematis, telah membantu banyak mahasiswa dalam mengatasi persoalan kesehatan mentalnya. Layanan konseling sebaya ini disebut sebagai pendampingan sebaya. Pada penelitian tersebut, pendampingan sebaya diberikan oleh seorang konselor sebaya, dengan pertimbangan besarnya pengaruh yang diberikan oleh teman sebaya, khususnya dari lingkaran pertemanan yang dekat. Konselor sebaya tersebut merujuk kepada seseorang yang memiliki peran menolong orang lain dan kedudukannya setara dengan konseli. Peran tersebut dapat didasari oleh pilihan sendiri atau tanggung jawab yang dipercayakan oleh suatu kelompok kepadanya secara kontemporer (Simmons, 1979) dan seorang konselor sebaya sebaiknya telah mendapatkan training sebelumnya (Turner, 1995).

Konseling sebaya dimaknai secara berbeda oleh setiap individu. Sebagian individu memahami konseling sebaya sebagai proses transformasi, fasilitas menyuarakan dan mendengarkan, serta cara untuk menghadapi perasaan kesepian dan isolasi. Pemaknaan pertama, transformasi diartikan sebagai proses individu mentransformasikan pengalaman traumatis pasca resiliensi ke dalam pelayanan dan upaya untuk menolong orang lain. Pemaknaan kedua, fasilitas menyuarakan dan mendengarkan adalah upaya individu untuk menyalurkan pengalaman yang dibungkam selama ini, dengan cara bercerita kepada konselor sebaya. Pemaknaan ketiga, cara untuk menghadapi perasaan kesepian dan isolasi mengarah pada proses konseling itu sendiri, di mana individu diharapkan dapat mereduksi berbagai emosi negatif, dengan menyadari bahwa ada orang (konselor sebaya) yang bisa memahami dan senantiasa menemani dirinya (Oulanova, dkk., 2014).

Ditinjau dari pengaplikasiannya, konseling sebaya juga dapat merujuk pada peer support atau dukungan sebaya. Dukungan sebaya ini berfungsi sebagai program yang mempermudah building rapport (membangun kepercayaan) pada individu dengan proses pemulihan gangguan mental. Selain itu, dukungan sebaya juga berfungsi untuk menghilangkan stigma mengenai kesehatan mental. Dalam hal

INSAN Jurnal Psikologi dan Kesehatan Mental

2021, Vol. 6(2), 90-105

doi: 10.20473/jpkm.v6i22021.90-105

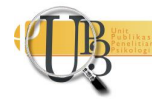


ini, penerima layanan dukungan sebaya menunjukkan harapan, motivasi, serta dukungan dan relasi sosial yang lebih luas. Sementara itu, penerima layanan cenderung mendapatkan diskriminasi dan prasangka dari individu di luar layanan dukungan sebaya (Mahlke, dkk., 2014).

Berdasarkan penjelasan-penjelasan sebelumnya, terdapat kecenderungan bahwa layanan konseling sebaya yang sifatnya nonformal lebih diminati oleh remaja dan dewasa awal dengan berbagai pertimbangan. Selain itu, layanan konseling sebaya tersebut dapat memberikan manfaat yang diharapkan. Dengan demikian, perlu untuk mempertimbangkan layanan ini sebagai bentuk layanan psikologis bagi remaja dan dewasa awal, khususnya di masa pandemi COVID-19, yang mana beberapa kebijakan telah memberikan dampak sosio-emosional tersendiri, khususnya bagi remaja.

Seiring perkembangan teknologi informasi dan komunikasi yang disertai adanya pandemi COVID-19, layanan konseling sebaya daring semakin diminati. Hal ini dapat dilihat dari peningkatan kehadiran layanan tersebut dalam dua tahun belakangan ini. Berdasarkan data yang dikemukakan oleh Into the Light bahwa setidaknya terdapat 22 daftar layanan konseling sebaya daring, di antaranya yaitu Alpas, Ibunda.id, Pijar Psikologi, dan Pulih Counseling (Into the Light, 2020). Naslund, Aschbrenner, Marsch, dan Bartels (2016) mengemukakan bahwa individu dengan masalah mental serius melaporkan manfaat dari berinteraksi dengan konselor sebaya secara daring, dengan adanya perasaan keterhubungan (connectedness) melalui kegiatan bercerita masalah personal. Dari penelitian tersebut juga ditemukan bahwa konseling sebaya secara daring membantu individu untuk melawan stigma melalui pengembangan diri dan harapan (hope). Layanan tersebut juga membantu individu untuk menyadari pentingnya menjaga kesehatan mental dan mengetahui akses layanan psikologis, yang mana hal ini merupakan promosi perilaku mencari bantuan layanan kesehatan mental. Penelitian tersebut sejalan dengan hasil kajian literatur dari Fortuna, dkk. (2020) yang menjelaskan bahwa mayoritas studi mengenai dukungan sebaya digital mengarah pada kelayakan, penerimaan, dan intervensi awal yang efektif, untuk meningkatkan keberfungsian partisipan dan mereduksi gejala-gejala maladaptif. Studi dari Nurafiani (2020) terhadap suatu layanan konsultasi daring @curhatalpas juga menemukan bahwa penggunaan layanan tersebut memiliki pengaruh yang kuat (48,6 persen) terhadap kepuasan pelayanan kesehatan mental partisipan.

Manfaat dari layanan tersebut dapat menunjukkan bahwa konseling secara daring dapat mereduksi tekanan dan gejala maladaptif yang dimunculkan dari kondisi stres. Dengan demikian, pada dasarnya konseling sebaya dan konseling secara daring dapat menjadi salah satu penerapan dari konsep Psychological First Aid (PFA) atau pertolongan pertama psikologis. PFA didefinisikan sebagai suatu pendekatan modular untuk menolong orang-orang yang telah mengalami kejadian yang dapat menimbulkan trauma, sehingga diharapkan dapat mengurangi tekanan dan meningkatkan fungsi adaptif jangka pendek hingga jangka panjang. Layanan PFA meliputi sejumlah komponen yaitu perencanaan strategis (persiapan dan pelatihan); pelayanan preventif (direncanakan dan diberikan sebelumnya untuk mengembangkan resiliensi psikososial); penyediaan layanan kemanusiaan dan kesejahteraan dasar; pemberian PFA oleh sumber daya manusia yang telah terlatih dan di bawah supervisi; proses screening, asesmen, intervensi kepada individu yang mengalami distres; serta pemberian rekomendasi pelayanan kesehatan mental primer maupun sekunder kepada individu yang dinilai membutuhkan (Bisson \& Lewis, 2009).

Pada dasarnya, PFA memiliki sejumlah aksi dan tujuan yaitu lebih mengenali penyintas dengan mengembangkan interaksi dan hubungan positif; membangun kenyamanan secara fisik dan emosional; (apabila dibutuhkan) menenangkan dan mendampingi penyintas untuk mengatasi kelelahan emosional; mengidentifikasi kebutuhan dan persoalan mendesak, mengumpulkan informasi tambahan, kemudian menentukan intervensi PFA yang sesuai; menawarkan bantuan praktis kepada penyintas dalam mengatasi kebutuhan dan persoalan mendesaknya; mereduksi distres melalui bantuan koneksi dengan agen sistem pendukung utama, seperti keluarga atau sahabat; menyediakan informasi kepada individu,

INSAN Jurnal Psikologi dan Kesehatan Mental

2021, Vol. 6(2), 90-105

doi: 10.20473/jpkm.v6i22021.90-105

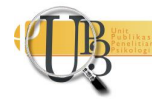


termasuk edukasi mengenai reaksi stres dan coping, yang dapat menolongnya untuk menangani kejadian sebagai stresor dan implikasinya; serta menghubungkan penyintas dengan layanan kesehatan mental yang dibutuhkan dan menginformasikan mengenai daftar layanan psikologis, yang mungkin akan dibutuhkan di masa datang (Ruzek, dkk., 2007).

Berdasarkan sekuensi gejala yang telah diuraikan, untuk berkontribusi terhadap kebutuhan akan pelayanan kesehatan mental di masa pandemi, Halo Jiwa Indonesia sebagai organisasi sosial yang bergerak dalam bidang peningkatan kesadaran kesehatan mental mengadakan program Ruang Refleksi Online (RRO). RRO adalah fasilitas pendampingan sebaya terhadap individu yang mengalami persoalan harian. Pelayanan tersebut dimaksudkan sebagai upaya preventif terhadap persoalan harian yang tergolong kategori ringan hingga sedang, sehingga tidak berlanjut sebagai penyakit mental yang serius. Dalam hal ini, pendamping sebaya yang telah mengikuti pelatihan 'Mendengarkan Secara Empatik' bertugas untuk mendengarkan cerita dari partisipan dan mengarahkannya kepada insight yang berguna untuk penyelesaian masalah di masa datang. Dalam penerapannya, partisipan yang mengikuti RRO berasal dari daerah yang berbeda-beda di Indonesia dan umumnya berasal dari kalangan usia remaja hingga dewasa awal. Pada dasarnya, RRO memiliki kekuatan dari segi pelayanan yang disediakan, di mana memadukan prinsip konseling sebaya, dukungan sebaya secara daring, dan PFA. Dengan demikian, RRO hadir sebagai tanggapan terhadap kebutuhan masyarakat akan pendampingan sebaya yang berbasis daring, dengan penerapan kode etik psikologi di masa pandemi COVID-19 dan dapat dikembangkan pascapandemi.

Laporan ini berfokus pada penggambaran program RRO tersebut sebagai suatu layanan pendampingan sebaya daring di Masa Pandemi COVID-19. Dengan demikian, laporan ini memberikan informasi dan insight terkait program yang dapat digunakan untuk mendukung pengembangan program serupa. Selain itu, laporan ini dapat menjadi bahan referensi untuk mengevaluasi konsep dan program konseling sebaya, dukungan sebaya, dan layanan psikologis daring yang berkembang pesat saat ini.

\section{E T O D E}

\section{Partisipan Intervensi}

Partisipan adalah peserta yang berada pada tahap perkembangan remaja dan dewasa awal (berusia sekitar 15 - 35 tahun) yang mendaftarkan diri dalam program pendampingan RRO. Jumlah partisipan yang terlibat adalah 90 orang $\left(M_{\text {usia }}=20,92 ; S D_{\text {usia }}=3,15 ; 92\right.$ persen perempuan $)$. Gambaran karakteristik lebih lanjut dapat dilihat pada Tabel 1.

Tabel 1. Karakteristik Partisipan

\begin{tabular}{lcc}
\hline \multicolumn{1}{c}{ Variabel } & Frekuensi & Presentase \\
\hline Jenis Kelamin & & \\
Perempuan & 83 & $92 \%$ \\
Laki-laki & 7 & $8 \%$ \\
Usia & & \\
$\quad<20$ tahun & 30 & $33 \%$ \\
$20-25$ tahun & 55 & $61 \%$ \\
$>25$ tahun & 5 & $6 \%$ \\
Sumber informasi & & \\
Instagram & 32 & $35.6 \%$ \\
Twitter & 24 & $26,7 \%$ \\
\hline
\end{tabular}

INSAN Jurnal Psikologi dan Kesehatan Mental 2021, Vol. 6(2), 90-105 


\begin{tabular}{lcc}
\hline \multicolumn{1}{c}{ Variabel } & Frekuensi & Presentase \\
\hline Facebook & 2 & $2.2 \%$ \\
Teman & 13 & $14.4 \%$ \\
Berbagai Medsos & 5 & $5.6 \%$ \\
WhatsApp & 1 & $1.1 \%$ \\
Tidak menjawab & 13 & $14.4 \%$ \\
\hline
\end{tabular}

\section{Prosedur Intervensi}

RRO merupakan fasilitas pendampingan sebaya, yang menjadi alternatif terhadap layanan profesional psikologis. Fasilitas ini tidak memberikan intervensi psikologis dan hanya terbatas pada mendengarkan dan menemani. Secara umum, kegiatan ini terikat oleh kode etik psikologi, di mana hak-hak partisipan, seperti asas kerahasiaan, dijamin sepenuhnya. Terdapat sembilan pendamping yang sebagian besar berlatarbelakang sarjana psikologi dan terdapat dua pendamping yang sedang menempuh magister profesi psikologi, dua pendamping dengan latar belakang magister sains psikologi dan satu orang pendamping dengan latar belakang teknik pangan yang sebelumnya telah mendapatkan pelatihan dari Psikolog. RRO dilaksanakan sebanyak delapan kloter yang dimulai dari 29 April hingga 29 November 2020.

Berikut diuraikan alur pelaksanaan RRO:

1. Partisipan mengisi formulir pendaftaran online yang tautannya telah dicantumkan di infografis. Dalam form tersebut, partisipan mengisi identitasnya dan mengusulkan pendampingnya sendiri. Profil singkat pendamping dapat dilihat di media sosial Instagram Halo Jiwa Indonesia. Selain itu, tidak lupa partisipan mengisi kontak yang bisa dihubungi.

2. Selanjutnya, admin akan mengolah data yang telah masuk dan menghubungi partisipan. Dalam hal ini, admin akan meminta usulan waktu dari partisipan yang akan disesuaikan dengan waktu pendamping.

3. Setelah waktu ditetapkan, admin akan mengingatkan pendamping dan partisipan mengenai jadwal pendampingannya.

4. Paling lambat 30 menit sebelum waktu pendampingan, admin akan mengkonfirmasi kesediaan partisipan dan agar kiranya partisipan bisa hadir selama kurang lebih satu jam, sebagaimana pendamping telah meluangkan waktunya.

5. Proses pendampingan dilaksanakan melalui media WhatsApp yang mana partispan dapat memilih fitur chat, baik pesan teks maupun pesan suara atau kombinasi keduanya, serta fitur panggilan. Terkadang, terdapat juga pendamping yang menggunakan panggilan selular secara langsung (melalui handphone) karena persoalan sambungan/jaringan yang tidak stabil apabila menggunakan WhatsApp.

6. Setelah pendampingan selesai, admin akan meminta partisipan untuk mengisi formulir umpan balik

\section{Pengukuran Efektivitas Intervensi}

Instrumen pengukuran yang digunakan bertujuan untuk mengetahui umpan balik dari partisipan terkait dengan hasil pendampingan, yang juga mengarah pada efektivitas pendampingan. Instrumen Umpan Balik RRO disusun sendiri oleh penulis yang juga merupakan penyelenggara dan pendamping program. Pengecekan keabsahan Instrumen dalam mengukur hasil program sesuai dengan aspek yang dikehendaki telah dilakukan oleh penulis yang dalam hal ini juga merupakan penyelenggara dan pendamping. Sebanyak lima orang pendamping dan penyelenggara dilibatkan dalam proses 
penyusunan sekaligus pengecekan keabsahan instrumen. Terdapat sembilan total pertanyaan, yang terdiri dari delapan pertanyaan terbuka dan satu pertanyaan tertutup. Pertanyaan yang secara khusus dianalisis adalah pertanyaan terkait masalah yang dipersepsikan, pikiran dan perasaan setelah mengikuti pendampingan, efek pendampingan, serta tanggapan tentang program, proses pendampingan dan pelayanan admin.

\section{Analisis Efektivitas Intervensi}

Data dianalisis dengan analisis tematik khususnya data dari pertanyaan terbuka. Data dari pertanyaan tertutup dianalisis dengan analisis statistik deskriptif berupa persentase jumlah respon. Selain itu, dilakukan pula analisis SWOT pada beberapa jawaban dari pertanyaan terbuka, terkait dengan program RRO dan pihak yang terlibat di dalamnya.

\section{ANALISIS EFEKTIVITAS INTERVENSI}

Tujuan laporan ini adalah untuk memberikan gambaran dan insight terkait program RRO yang memadukan konsep konseling sebaya, pertolongan pertama psikologis, serta layanan psikologis online. Bagian hasil mengeksplorasi lebih lanjut tentang pemetaan masalah-masalah yang diidentifikasi oleh peserta saat proses pendaftaran, hasil dari pendampingan serta analisis kekuatan, kelemahan, peluang dan ancaman dari program RRO.

\section{Pemetaan Masalah}

Tabel 2 menunjukkan kategori dan sub-kategori persoalan-persoalan peserta yang memilih mengikuti program RRO, berdasarkan pada pengelompokan usia.

Tabel 2. Pemetaan Masalah Peserta Berdasarkan Usia

\begin{tabular}{|c|c|c|c|c|c|c|c|c|}
\hline \multirow{3}{*}{ Kategori Masalah } & \multicolumn{6}{|c|}{ Kategori Usia } & \multirow{2}{*}{\multicolumn{2}{|c|}{ Total }} \\
\hline & \multicolumn{2}{|c|}{$<20$ tahun } & \multicolumn{2}{|c|}{20 - 25 tahun } & \multicolumn{2}{|c|}{$>25$ tahun } & & \\
\hline & $n$ & $f(\%)$ & $n$ & $f(\%)$ & $n$ & $f(\%)$ & $n$ & $f(\%)$ \\
\hline 1. Lain-Lain dan Campuran & $\mathbf{0}$ & $\mathbf{0 , 0}$ & 3 & 5,5 & 1 & 20 & 4 & 4,4 \\
\hline Umum & 0 & 0,0 & 1 & 1,8 & 0 & 0 & 1 & 1,1 \\
\hline Beberapa Masalah & 0 & 0,0 & 2 & 3,6 & 1 & 20 & 3 & 3,3 \\
\hline 2. Personal/Pribadi & 26 & 86,7 & 39 & 70,9 & 4 & 80 & 69 & 76,7 \\
\hline Adiksi & 1 & 3,3 & 0 & 0,0 & 0 & 0 & 1 & 1,1 \\
\hline Kecemasan & 2 & 6,7 & 7 & 12,7 & 0 & 0 & 9 & 10,0 \\
\hline Pikiran-Pikiran Negatif & 1 & 3,3 & 0 & 0,0 & 1 & 20 & 2 & 2,2 \\
\hline Perkembangan & 0 & 0,0 & 2 & 3,6 & 0 & 0 & 2 & 2,2 \\
\hline Kepribadian & 2 & 6,7 & 4 & 7,3 & 0 & 0 & 6 & 6,7 \\
\hline Masalah Fisiopsikologis & 0 & 0,0 & 1 & 1,8 & 0 & 0 & 1 & 1,1 \\
\hline Manajemen Diri & 19 & 63,3 & 20 & 36,4 & 3 & 60 & 42 & 46,7 \\
\hline Pengalaman Traumatis & 1 & 3,3 & 5 & 9,1 & 0 & 0 & 6 & 6,7 \\
\hline 3. Relasional & 4 & 13,3 & 13 & 23,6 & $\mathbf{0}$ & $\mathbf{0}$ & 17 & 18,9 \\
\hline
\end{tabular}




\begin{tabular}{|c|c|c|c|c|c|c|c|c|}
\hline \multirow{3}{*}{ Kategori Masalah } & \multicolumn{6}{|c|}{ Kategori Usia } & \multirow{2}{*}{\multicolumn{2}{|c|}{ Total }} \\
\hline & \multicolumn{2}{|c|}{$<20$ tahun } & \multicolumn{2}{|c|}{20 - 25 tahun } & \multicolumn{2}{|c|}{$>25$ tahun } & & \\
\hline & $n$ & $f(\%)$ & $n$ & $f(\%)$ & $n$ & $f(\%)$ & $n$ & $f(\%)$ \\
\hline Masalah Terkait Keluarga & 1 & 3,3 & 1 & 1,8 & 0 & 0 & 2 & 2,2 \\
\hline Masalah Terkait Pekerjaan & 0 & 0,0 & 1 & 1,8 & 0 & 0 & 1 & 1,1 \\
\hline Pelecehan Seksual & 0 & 0,0 & 1 & 1,8 & 0 & 0 & 1 & 1,1 \\
\hline Relasi anak-orang tua & 0 & 0,0 & 3 & 5,5 & 0 & 0 & 3 & 3,3 \\
\hline Relasi interpersonal & 3 & 10,0 & 7 & 12,7 & 0 & 0 & 10 & 11,1 \\
\hline Total & 30 & 100,0 & 55 & 100,0 & 5 & 100 & 90 & 100,0 \\
\hline
\end{tabular}

Dari Tabel 2 dapat diketahui bahwa sebagian besar masalah partisipan yang diperbincangkan di program RRO adalah masalah yang bersifat personal atau berpusat pada diri sendiri (76,7 persen). Secara khusus, masalah personal paling banyak berkaitan dengan masalah manajemen diri $(46,7$ persen), kemudian diikuti oleh masalah kecemasan (10 persen). Berkaitan dengan masalah yang bersifat relasional atau berhubungan dengan orang lain (18,9 persen), masalah yang paling banyak adalah masalah terkait relasi interpersonal dengan orang lain, meliputi relasi pertemanan dan relasi romantis yang tidak sehat (toxic) serta menjadi korban perundungan.

\section{Efek Pendampingan}

Peneliti menganalisis jawaban dari pertanyaan terkait dengan pikiran dan perasaan setelah pendampingan serta efek dari pendampingan untuk menelaah hasil dari pendampingan sebaya. Gambar 1 menunjukkan bahwa kebanyakan partisipan merasakan kelegaan setelah mengikuti sesi pendampingan (43 persen) serta merasa lebih baik dan tenang (22,8 persen). Hal ini dapat menunjukkan bahwa program ini memang dapat mereduksi ketegangan ataupun tekanan yang dirasakan partisipan sebelum mengikuti sesi pendampingan.

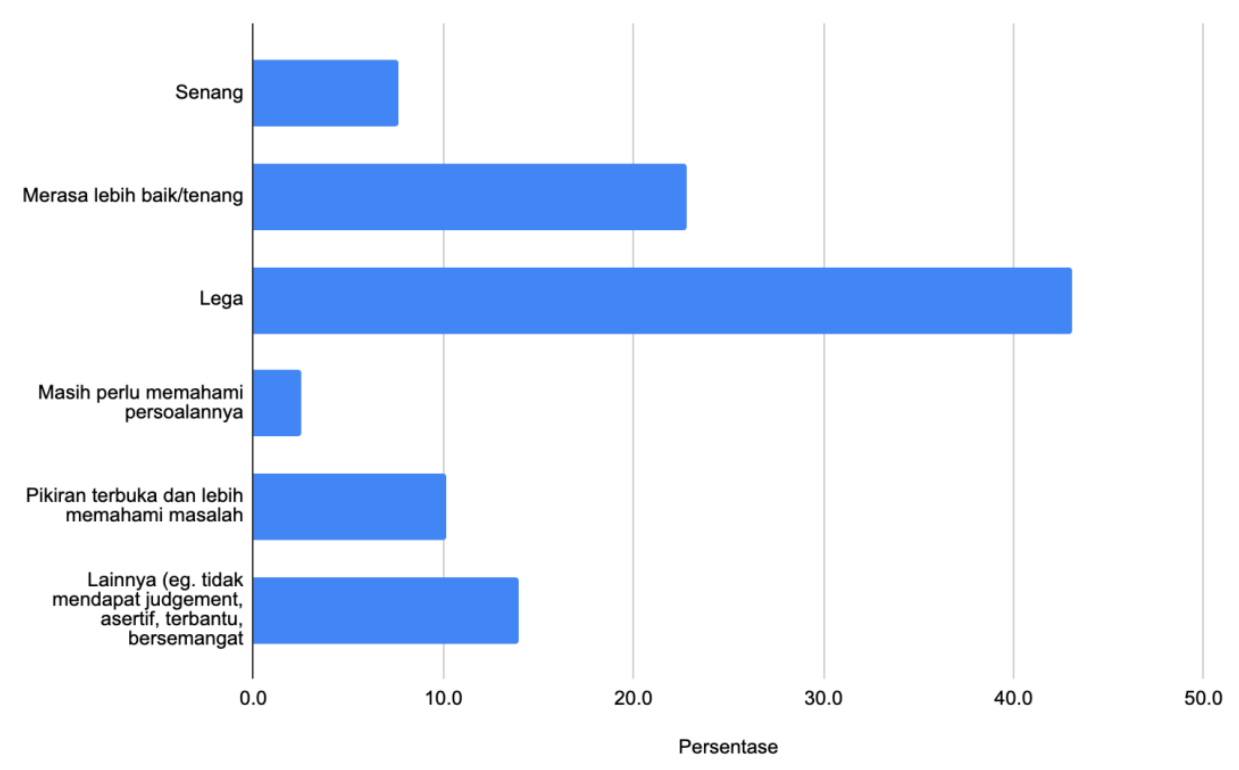

Gambar 1. Pikiran dan Perasaan setelah Pendampingan 
Selanjutnya, Gambar 2 menunjukkan efek dari sesi pendampingan yang dipersepsikan oleh partisipan. Hampir sebagian besar (44,3 persen) partisipan merasakan bahwa program ini sangat membantu dan sekitar 39 persen mengatakan cukup membantu. Dengan demikian, dapat dikatakan bahwa secara umum program ini dipersepsikan membantu atau memberikan efek oleh partisipan. Namun demikian, masih ada sekitar 6 persen partisipan yang belum merasa terbantu atau belum merasakan efeknya.

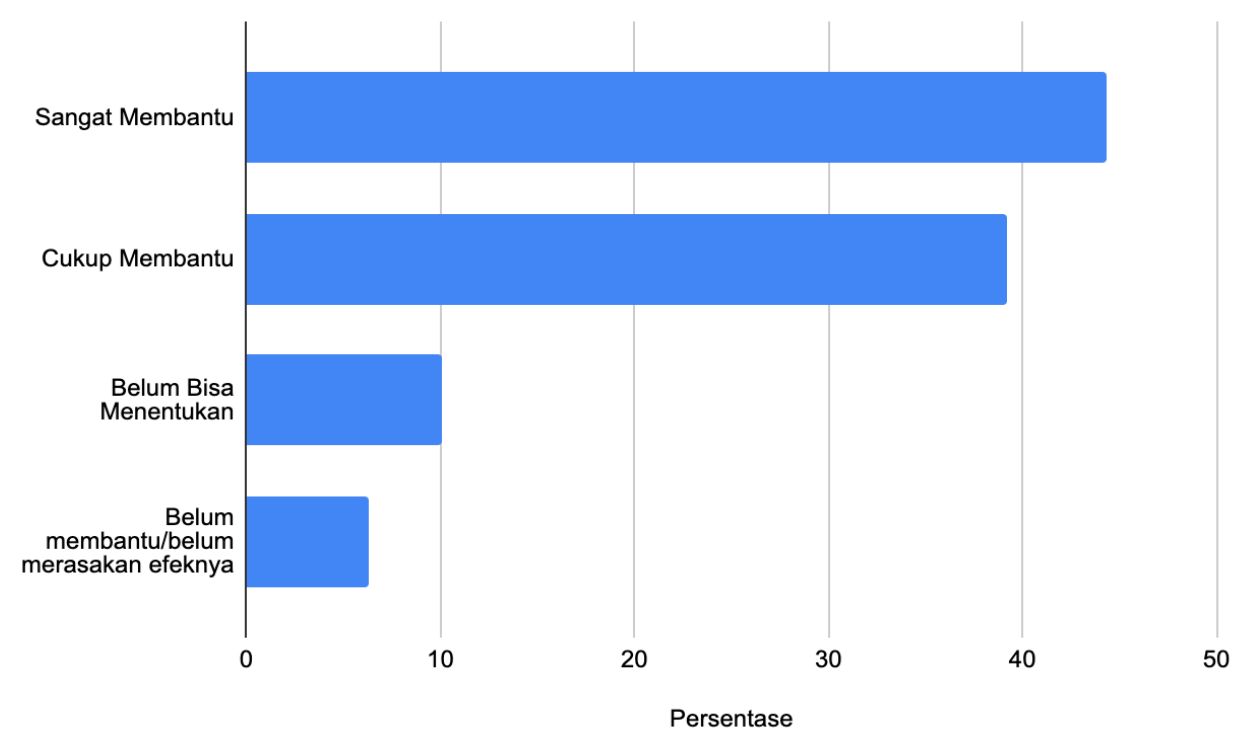

Gambar 2. Efek Pendampingan yang Dipersepsikan

\section{Analisis Kekuatan, Kelemahan, Peluang dan Ancaman (SWOT)}

Analisis SWOT disusun berdasarkan masukan ataupun saran dari berbagai pihak yang terlibat dalam program ini, yaitu pendamping, admin dan terutama peserta yang langsung mengisi formulir umpan balik setelah proses pendampingan. Selain itu, analisis juga didasarkan pada observasi proses pendampingan RRO itu sendiri serta observasi berbagai platform/organisasi yang memberikan pelayanan serupa. Tabel 3 menunjukkan hasil Analisis SWOT program RRO. Hasil dari analisis SWOT dapat menjadi pertimbangan bagi pengembangan program RRO atau program yang menggunakan konsep dasar yang serupa, khususnya yang dilakukan dalam jaringan.

Tabel 3. Hasil Analisis SWOT

\begin{tabular}{lll}
\hline Internal & \multicolumn{1}{c}{ Kekuatan (S) } & \multicolumn{1}{c}{ Kelemahan (W) } \\
\hline & $\begin{array}{l}\text { 1. Admin yang dinilai cepat } \\
\text { tanggap dan komunikatif }\end{array}$ & $\begin{array}{l}\text { 1. Masih ada kekurangan dalam } \\
\text { hal manajemen layanan. }\end{array}$ \\
& $\begin{array}{l}\text { 2. Keterampilan dan } \\
\text { pengetahuan dari } \\
\text { pendamping sebaya. Halo } \\
\text { Jiwa memberikan pelatihan }\end{array}$ & $\begin{array}{l}\text { 2. Jumlah partisipan yang } \\
\text { dibatasi karena menyesuaikan } \\
\text { dengan kemampuan dan } \\
\text { kesediaan pendamping }\end{array}$ \\
\hline
\end{tabular}

INSAN Jurnal Psikologi dan Kesehatan Mental 2021, Vol. 6(2), 90-105 
Mendengar dengan Empati serta PFA

3. Adanya kebebasan peserta untuk memilih fitur dari media komunikasi (teks atau suara)

4. Berbasis jaringan sehingga pendampingan bisa dilakukan dengan jarak jauh

5. Partisipan merasa lebih terbuka karena berbicara dengan seseorang yang tidak judgemental dan kurang lebih sebaya.

6. Partisipan merasa aman dan terjaga kerahasiaannya. sebaya.

3. Waktu pendampingan yang dinilai relatif singkat (1 jam), sehingga dapat berimplikasi pada kurangnya waktu untuk melakukan building rapport.

4. Tidak ada penggunaan fitur video dalam media komunikasi.

5. Belum ada pengukuran pretest ataupun asesmen pendahuluan sebelum sesi pendampingan dilakukan

6. Kehilangan kesan-kesan nonverbal yang dapat menjadi informasi tambahan bagi pendamping sebaya yang bermanfaat untuk pendampingan

7. Tidak bisa sepenuhnya memonitor aktivitas partisipan selama sesi pendampingan berlangsung.

\section{Peluang (0)}

1. Pandemi COVID-19 yang berimplikasi pada kebijakan pembatasan aktivitas sosial masyarakat

2. Perkembangan teknologi informasi dan komunikasi (internet dan media sosial)

3. Psikolog-psikolog muda yang ingin mencari pengalaman lapangan/konseling

4. Platform lain yang sama-sama mulai mengembangkan program layanan psikologis formal / profesional maupun nonformal
SO

1. Bekerja sama dengan platform lain yang sudah lebih berkembang (advanced) layanannya

2. Bekerja sama dengan psikolog yang lebih profesional

3. Promosi melalui media sosial

4. Pengembangan konsep pendampingan sebaya, kelompok dukungan, dan PFA berbasis jaringan
WO

1. Pengembangan program menjadi layanan online yang lebih tersistematis dan berbasis website ataupun aplikasi smartphone dengan fitur yang tidak dibatasi pada chat dan telpon, melainkan ada pilihan fitur lain seperti video.

2. Adanya asesmen awal untuk mengetahui kondisi awal peserta, terutama berkaitan dengan perasaan dan pikirannya.

\section{Ancaman (T)}

ST

1. Peran Admin dalam mendukung peserta untuk mengikuti program dengan baik dan penuh perhatian.

2. Adanya ground rules terstandar yang dikirimkan kepada peserta setelah mendaftar dan menentukan jadwal.

\section{Meminimalkan pengaruh dari peserta yang kurang berkomitmen dan merasa ketergantungan melalui adanya aturan yang tegas dari pihak pengelola program.} yang kemudian dapat memberikan kesan umum yang negatif tentang pelayanan ini.

3. Ketergantungan peserta terhadap

1. Kecenderungan anonimitas besar dirasakan oleh partisipan karena partisipan sendiri yang kurang optimal dalam mengikuti sesi, SAN Jurnal Psikologi dan Kesehatan Mental 2021, Vol. 6(2), 90-105 doi: 10.20473/jpkm.v6i22021.90-105

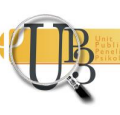


pendampingnya di luar jam pelayanan.

4. Ancaman pihak-pihak yang tidak bertanggung jawab yang dengan sengaja berusaha mengakses percakapan peserta dan pendamping (misalnya, hacker)
3. Mengoptimalkan

keterampilan dari

pendamping sebaya

4. Mengoptimalkan promosi

program dengan bentuk

yang bervariasi

5. Meningkatkan pengaturan

privasi akun platform

media sosial yang

digunakan dalam program

layanan baik oleh peserta

maupun pendamping.

\section{I S K U S I}

Laporan ini mengkaji evaluasi program RRO sebagai suatu layanan pendampingan sebaya daring di masa pandemi COVID-19. Beberapa temuan yang perlu digarisbawahi dari studi ini adalah bahwa pada umumnya masalah-masalah yang dilaporkan oleh remaja dan dewasa muda sebagai partisipan program merupakan masalah yang digolongkan pada masalah personal, terutama manajemen diri dan kecemasan. Selanjutnya, program ruang refleksi sebagai layanan konseling sebaya daring dapat memberikan hasil positif sehingga dapat mendukung riset-riset sebelumnya. Berkaitan dengan manfaatnya tersebut, program RRO dapat membuat partisipan menjadi lega dan merasa lebih baik sehingga program ini dapat menjadi bentuk Pertolongan Pertama Psikologis Daring. Terakhir, program ini juga memiliki kekuatan, kelemahan, peluang dan ancaman yang dapat dijadikan pertimbangan untuk mengembangkan program dengan konsep serupa.

Hasil penelitian ini, mendukung beberapa studi sebelumnya terkait efek positif. Chardon, dkk. (2011) dalam studinya menemukan pendampingan sebaya yang dilakukan secara daring mempermudah remaja menggunakan dan mengakses sumber bantuan dalam kesehatan mental. Menurut Chardon, dkk, pendampingan berbasis daring ini sangat memainkan peran penting dalam menyediakan aksesibilitas pelayanan, terutama untuk remaja. Selain itu, Tirel, dkk. (2020) turut menjelaskan bahwa pendampingan melalui internet dapat membantu meningkatkan motivasi individu karena keterjangkauan akses dan dianggap lebih praktis. Rasa kepercayaan yang kuat terhadap pendampingan daring dikarenakan bersifat privasi dan individu tidak perlu bertatap muka. Hal ini dapat membantu untuk meminimalkan intensitas emosional yang terjadi. Selain itu, meminimalisir biaya sumber daya yang harus dikeluarkan.

Hasil program pendampingan sebaya secara daring, kemudian dianalisis lebih lanjut. Ditinjau dari data demografi partisipan, diketahui bahwa mayoritas partisipan yang terlibat didominasi oleh perempuan daripada laki-laki. Kondisi ini nampak sejalan dengan Chan dan Hayashi (2010) yang menemukan bahwa laki-laki, khususnya di negara Asia cenderung menginternalisasi stereotip maskulin dalam peran gender mereka. Laki-laki dituntut membatasi respon emosi mereka dan lebih mengedepankan logika, sehingga saat ada masalah cenderung ditekan dan lebih sedikit mencari bantuan professional untuk mengatasi masalahnya. Padahal dengan kecenderungan menutupi emosinya, bisa membuat lakilaki semakin rentan untuk mengalami gangguan yang lebih parah terkait kondisi kesehatan mentalnya (Parent dkk., 2018). Sedangkan, perempuan lebih cenderung terbuka terhadap intervensi psikologis (Wang dkk., 2007). 
Penelitian ini juga memetakan permasalahan yang dialami oleh partisipan selama masa pandemi COVID-19. Secara umum, partisipan memiliki permasalah yang lebih berpusat pada dirinya sendiri, dengan kategori tertinggi pada permasalahan manajemen diri (46,7 persen) dan diikuti oleh masalah kecemasan (10 persen). Temuan ini sejalan dengan studi Fitria dan Ifdil (2020) yang menemukan bahwa selama masa pandemi COVID-19 terdapat 54 persen remaja mengalami kecemasan atas situasi yang mereka jalani. Pietrabissa dan Simpson (2020) juga menjelaskan bahwa di tengah situasi krisis seperti Pandemi COVID-19 ini, manusia cenderung dihantui oleh masalah kecemasan dan depresi sebagai konsekuensi psikologis akibat pengaruh tekanan internal dan eksternal. Perasaan-perasaan negatif seperti rasa takut dan khawatir memang sangat wajar terjadi di tengah situasi pandemi ini, sehingga kebutuhan untuk mendapatkan dukungan sosial dinilai sangat berharga (Zhang \& Ma, 2020).

Program RRO merupakan salah satu wujud dukungan sosial yang dilakukan oleh Halo Jiwa Indonesia sebagai organisasi sosial yang bergerak dalam bidang kesadaran kesehatan mental. Kehadiran program ini sebagai bentuk pertolongan pertama psikologis bagi individu yang mengalami masalah dan membutuhkan dukungan serta pendampingan sebaya. Di tengah situasi krisis, bantuan sejenis ini memang sangat dibutuhkan untuk meredakan perasaan negatif yang dialami seseorang sehingga dapat lebih tenang dan berpikiran terbuka dalam merencanakan langkah hidup selanjutnya (Hechanova, dkk., 2015; Lee dkk., 2017). Hal ini nampak sejalan dengan hasil pelayanan konseling yang dinilai oleh mayoritas partisipan sebagai 'sangat membantu' dan 'cukup membantu' serta dihayati memberikan perasaan lega dan tenang setelah mengikuti sesi pendampingan yang diberikan. Di tengah keterbatasan yang dihadapi oleh proses konseling dalam jaringan dan menggunakan media chat, para partisipan mampu merasakan manfaat dari kegiatan tersebut. Efektifitas pemberian layanan jarak jauh seperti ini pada penelitian sebelumnya diketahui cukup baik dan mampu memberi rasa kepuasan yang positif pada klien, bahkan dapat terintegrasi pada intervensi psikologis secara berkelanjutan (Thompson, 2016).

Sebagai layanan yang dilaksanakan dalam jaringan, program RRO tidak berbeda dengan layanan konseling daring lainnya yang memiliki keterbatasan. Pada penelitian ini menemukan masih ada sekitar (6 persen) partisipan yang belum merasa terbantu atau belum merasakan pengaruh ketika mengikuti program ini. Hal ini dikarenakan beberapa kondisi yang mempengaruhi, antara lain kurangnya manajemen layanan, waktu pendampingan serta sumberdaya konselor. Keterbatasan lainnya yang ditemukan selama program berlangsung adalah tidak tersedianya media video, tidak dilakukan pengukuran pre-test ataupun asesmen, dan tidak sepenuhnya bisa memonitor aktivitas partisipan. kondisi tersebut dianggap penting dan perlu mendapat perhatian khusus karena berdampak pada proses berlangsungnya pendampingan dengan partisipan.

Beberapa penelitian sebelumnya turut menemukan beberapa kekurangan ketika melakukan pendampingan dalam jaringan. Kekurangan tersebut antara lain, pemahaman individu dalam menggunakan teknologi, kestabilan jaringan yang tidak menentu, sulitnya konselor mengetahui gestur tubuh dan ekspresi wajah dari klien (Tirel, dkk., 2020). Namun demikian, metode pendampingan yang dilakukan dalam jaringan bisa menjadi komponen penting dalam memberikan kontribusi terhadap pemecahan persoalan yang dialami individu. Seperti yang dikemukakan Fitria dan Ifdil (2020), pendampingan yang dilakukan dalam jaringan cukup efektif, jika permasalahan yang dihadapi membutuhkan penyelesaian sesegera mungkin, sementara terkendala jarak untuk mencari bantuan secara tatap muka. Pendampingan daring dapat dijadikan alternatif penyelesaian masalah. Selain itu, jika pendampingan daring dilakukan dengan media yang memadai, secara teknis seperti menggunakan video dan memiliki jaringan yang stabil, maka hal ini hampir sama dengan melakukan konseling secara langsung. Hasil penelitian Zamani, dkk. (2010) juga menemukan sebanyak 20 remaja memberikan penilaian yang positif selama mengikuti sesi konseling secara daring. Selain itu, Tirel, dkk., (2020) juga mengemukakan efektivitas pelaksanaan konseling sebaya dalam jaringan dilihat dari frekuensi dan

INSAN Jurnal Psikologi dan Kesehatan Mental

2021, Vol. 6(2), 90-105

doi: 10.20473/jpkm.v6i22021.90-105

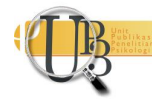


intensitas terjadinya proses konseling. Hal ini dapat meningkatkan efektivitas layanan daring dan memberikan manfaat bagi individu pengguna di tengah kekurangan yang dimiliki.

Pemanfaatan media daring dalam berbagai aspek kehidupan manusia di tengah era digital terus berkembang pesat, tidak terkecuali dalam bidang pelayanan kesehatan mental. Kondisi ini merupakan sebuah peluang yang seyogianya dimanfaatkan para pegiat kesehatan mental, dalam hal ini RRO yang diinisiasi Halo Jiwa adalah salah satu di antaranya. Pelayanan dalam lingkup daring seperti yang sudah dilakukan pada penelitian ini memang masih membutuhkan banyak evaluasi dalam rangka meningkatkan pelayanan yang diberikan. Hal seperti batasan waktu, jenis pelayanan yang diberikan dan etika yang masih belum ajeg dari segi pelayanan psikologi daring adalah hal yang hendaknya bisa ditingkatkan. Di samping itu, pengembangan layanan melalui penggunaan media telepon atau video conference sangat disarankan untuk meningkatkan kualitas pelayanan sehingga dapat meminimalisir keterbatasan yang ada pada layanan tidak langsung kepada klien.

Mengingat banyak hal yang perlu ditingkatkan dalam kajian ini, penelitian ini memiliki keterbatasan yang patut dipertimbangkan oleh peneliti selanjutnya. Meskipun jumlah responden yang terlibat memuaskan, namun efektivitas layanan RRO tidak dapat digeneralisasi dan hanya terbatas dalam program ini. Laporan ini tidak turut menganalisis lebih lanjut permasalahan responden secara lebih khusus dan membedakannya dalam proses analisis. Selanjutnya, RRO sangat bergantung dengan dukungan media, sehingga jika media bermasalah proses konseling menjadi terhambat. Selain itu, instrumen pengukuran yang digunakan tidak didasarkan pada dimensi teoretis tertentu terkait konseling sebaya dan tidak ada pengukuran awal mengenai kondisi psikologis responden sehingga kondisi awal responden tidak dapat dikontrol. Pelibatan variabel-variabel lain sebagai bentuk kontrol juga tidak dipertimbangkan dalam program ini. Untuk kepentingan penelitian selanjutnya, laporan ini dapat menjadi bahan pertimbangan untuk mengetahui keefektifan ketika melakukan layanan pendampingan dalam jaringan, mengingat tidak mudah bagi individu untuk terbuka terhadap permasalahan yang dihadapinya. Penulis selanjutnya juga dapat mengembangkan penelitian dengan menganalisis keefektifan layanan daring sampai pada intervensi penyelesaian masalah pada individu.

\section{S I M P U L A N}

Penelitian ini dilakukan untuk mengetahui gambaran hasil dari program RRO sebagai suatu layanan pendampingan sebaya daring di masa pandemi COVID-19. Studi ini memberikan hasil bahwa sebagian besar responden memberikan penilaian yang memuaskan terhadap program ruang refleksi yang dilakukan secara daring. Temuan ini juga mengimplikasikan bahwa layanan konseling daring dapat menjadi alternatif yang efektif untuk membantu mengurangi stres yang dirasakan serta menemukan informasi dan solusi dalam menyelesaikan masalah yang dihadapinya. Penelitian ini turut merekomendasikan untuk bisa mempromosikan dan memberdayakan penggunaan layanan kesehatan mental secara daring. Promosi layanan ini hendaknya dilakukan dengan mempertimbangkan destigmatisasi dan kesenjangan terhadap pelayanan kesehatan mental.

Program RRO yang dilakukan secara daring memang memberikan hasil yang positif. Meskipun begitu, beberapa kelemahan pendampingan sebaya secara daring juga perlu untuk dipertimbangkan. Dibutuhkan sosialisasi untuk mempromosikan program layanan ini, mengingat situs-situs psikologi banyak menawarkan jasanya demi keberlangsungan hidup yang nyaman bagi individu di tengah masa pandemi. Selain itu, dibutuhkan juga pelatihan peningkatan keterampilan bagi konselor dalam melakukan pelayanan dalam jaringan. Dengan demikian individu tidak perlu ragu berkonsultasi tanpa perlu tatap muka langsung. Berkaitan dengan metode pelaksanaan, bentuk penelitian untuk mengevaluasi keefektifan suatu program perlu untuk mempertimbangkan adanya pengukuran awal

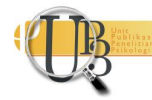


ataupun bentuk-bentuk pre-test serta mempertimbangkan beberapa variabel-variabel yang dapat dikontrol dalam pengujian efektivitasnya

\section{U C A P A N T ERIMA KASI H}

Kami mengucapkan terima kasih kepada seluruh pendamping RRO yang telah memberikan pelayanan sepenuh hati kepada para partisipan. Secara tidak langsung, semua pendamping telah berkontribusi terhadap terwujudnya naskah ini. Terima kasih juga kami haturkan kepada tim media sosial Halo Jiwa Indonesia yang telah mempublikasikan program ini secara aktif sehingga dapat menjangkau audiens yang membutuhkan pelayanan.

\section{DEKLARASI POTENSI TERJADINYAKONFLIK KEPENTINGAN}

Syurawasti Muhiddin, Afga Yudistikhar, Azmul Fuady Idham, Sitti Muthia Maghfirah Massinai, Syarifa Nadhrah Mustamin, dan Griselda Maria Ancela Wodong tidak bekerja, menjadi konsultan, memiliki saham, atau menerima dana dari perusahaan atau organisasi manapun yang mungkin akan mengambil untung dari diterbitkannya naskah ini.

\section{PUSTAKA ACUAN}

Aziz, Z. A., Ayu, D. A., Bancin, F. M., Syara, S. G., Manalu, W. B., Artika, R., Lia, S. F., Tanjung, L. P., Bangun, C. A. B., \& Limbong, F. W. (2021). Gambaran Kesehatan Mental Mahasiswa di Masa Pandemi Covid19. Jurnal Dunia Kesmas, 10(1), 130-135.

Bisson, J. I., \& Lewis, C. (2009). Systematic review of psychological first aid. Commissioned by the World Health Organization.

Brooks, S. K., Webster, R. K., Smith, L. E., Woodland, L., Wessely, S., Greenberg, N., \& Rubin, G. J. (2020). The psychological impact of quarantine and how to reduce it: Rapid review of the evidence. The Lancet, 395(10227), 912-920. https://doi.org/10.1016/S0140-6736(20)30460-8

Cerully, J. L., Acosta, J. D., \& Sloan, J. (2018). Mental Health Stigma and Its Effects on Treatment-Related Outcomes: A Narrative Review. Military Medicine, 183(11-12), e427-e437.

https://doi.org/10.1093/milmed/usx219

Chan, R. K. H., \& Hayashi, K. (2010). Gender Roles and Help-Seeking Behaviour: Promoting Professional Help among Japanese Men. Journal of Social Work, 10(3), 243-262.

https://doi.org/10.1177/1468017310369274

Chardon, L., Bagraith, K. S., \& King, R. J. (2011). Counseling activity in single-session online counseling with adolescents: An adherence study. Psychotherapy Research, 21(5), 583-592.

https://doi.org/10.1080/10503307.2011.592550

Corrigan, P. (2004). How stigma interferes with mental health care. American Psychologist, 59(7), 614625. https://doi.org/10.1037/0003-066X.59.7.614

Damayanti, A., \& Wahida, D. (2019). Pengelolaan Program Konselor Sebaya oleh Career Development Center (CDC) Fakultas Ilmu Sosial Dan Ilmu Politik Universitas Gadjah Mada. Proceeding Indonesian Carrier Center Network (ICCN) Summit 2019, 1(1), 75-81.

INSAN Jurnal Psikologi dan Kesehatan Mental

2021, Vol. 6(2), 90-105

doi: 10.20473/jpkm.v6i22021.90-105

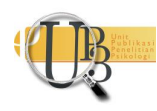


Fitria, L., \& Ifdil, I. (2020). Kecemasan remaja pada masa pandemi Covid -19. Jurnal EDUCATIO: Jurnal Pendidikan Indonesia, 6(1), 1. https://doi.org/10.29210/120202592

Fortuna, K. L., Naslund, J. A., LaCroix, J. M., Bianco, C. L., Brooks, J. M., Zisman-Ilani, Y., Muralidharan, A., \& Deegan, P. (2020). Digital peer support mental health interventions for people with a lived experience of a serious mental illness: Systematic review. JMIR mental health, 7(4), e16460. https://doi.org/10.2196/16460

Hechanova, R. M., Ramos, P. A. P., \& Waelde, L. (2015). Group-based mindfulness-informed psychological first aid after Typhoon Haiyan. Disaster Prevention and Management, 24(5), 610-618. https://doi.org/10.1108/DPM-01-2015-0015

Into The Light. (2020). Layanan Konseling Online. Diakses pada 1 Juli 2021 dari https://www.intothelightid.org/tentang-bunuh-diri/layanan-konseling-online/

Lee, J.-S., You, S., Choi, Y.-K., Youn, H., \& Shin, H. S. (2017). A preliminary evaluation of the training effects of a didactic and simulation-based psychological first aid program in students and school counselors in South Korea. PLOS ONE, 12(7), e0181271.

https://doi.org/10.1371/journal.pone.0181271

Mahlke, C. I., Krämer, U. M., Becker, T., \& Bock, T. (2014). Peer support in mental health services. Current opinion in psychiatry, 27(4), 276-281. https://doi.org/10.1097/YC0.0000000000000074

Manumba, R., \& Hamid, A. Y. S. (2020). Factors Related to Seeking Help in People with Mental Disorders. Jurnal Ilmu Keperawatan Jiwa, 3(4), 391-402.

Naslund, J. A., Aschbrenner, K. A., Marsch, L. A., \& Bartels, S. J. (2016). The future of mental health care: Peer-to-peer support and social media, Epidemiology and Psychiatric Sciences, 25, 113-122. https://doi.org/10.1017/S2045796015001067

Nurafiani, A. D. (2020). Pengaruh E-konseling Akun LINE@ CurhatAlpas Terhadap Kepuasan Pelayanan Kesehatan Mental Pengguna. Universitas Jenderal Soedirman.

Oulanova, O., Moodley, R., \& Seguin, M. (2014). From suicide survivor to peer counselor: Breaking the silence of suicide bereavement. OMEGA-Journal of death and dying, 69(2), 151-168.

https://doi.org/10.2190/OM.69.2.dhttps://doi.org/10.2190/OM.69.2.dhttps://doi.org/10.2190/0 M.69.2.d

Parent, M. C., Hammer, J. H., Bradstreet, T. C., Schwartz, E. N., \& Jobe, T. (2018). Men's Mental Health Help-Seeking Behaviors: An Intersectional Analysis. American Journal of Men's Health, 12(1), 64-73. https://doi.org/10.1177/1557988315625776

Pietrabissa, G., \& Simpson, S. G. (2020). Psychological Consequences of Social Isolation During COVID19 Outbreak. Frontiers in Psychology, 11, 2201. https://doi.org/10.3389/fpsyg.2020.02201

Rasyida, A. (2019). Faktor yang menjadi hambatan untuk mencari bantuan psikologis formal di kalangan mahasiswa. Persona: Jurnal Psikologi Indonesia, 8(2), 193-207.

https://doi.org/10.30996/persona.v8i2.2586 
Rickwood, D. \& Thomas. (2012). Conceptual measurement framework for help-seeking for mental health problems. Psychology Research and Behavior Management, 173.

https://doi.org/10.2147/PRBM.S38707

Ridha, A. A. (2019). Penerapan konselor sebaya dalam mengoptimalkan fungsi layanan bimbingan konseling di sekolah. Jurnal Psikologi, 15(1), 25-34.

Riset Kesehatan Dasar (RISKESDAS). (2019). Laporan Nasional Riskesdas 2018. Jakarta: Lembaga Penerbit Badan Penelitian dan Pengembangan Kesehatan.

Ruzek, J. I., Brymer, M. J., Jacobs, A. K., Layne, C. M., Vernberg, E. M., \& Watson, P. J. (2007).

Psychological first aid. Journal of Mental Health Counseling, 29(1), 17-49.

https://doi.org/10.17744/mehc.29.1.5racqxjueafabgwp

Simmons, R. (1979). Peer Counseling: An In-Depth Look at Training Peer Helpers and Peer Power:

Becoming an Effective Peer Helper (workbook) H. Dean Gray and Judy Tindall Muncie, Ind.:

Accelerated Development, 1978. Journal of Teacher Education, 30(5), 49-49.

ttps://doi.org/10.1177/002248717903000523

Stanley, I. H., Hom, M. A., \& Joiner, T. E. (2018). Modifying mental health help-seeking stigma among undergraduates with untreated psychiatric disorders: A pilot randomized trial of a novel cognitive bias modification intervention. Behaviour Research and Therapy, 103, 33-42.

https://doi.org/10.1016/j.brat.2018.01.008

Thompson, R. (2016). Psychology at a Distance: Examining the Efficacy of Online Therapy. https://doi.org/10.15760/honors.292

Tirel, M., Rozgonjuk, D., Purre, M., \& Elhai, J. D. (2020). When do people seek internet counseling? Exploring the temporal patterns of initial submissions to online counseling services. Journal of Technology in Human Services, 38(2), 184-202. https://doi.org/10.1080/15228835.2018.1561348

Turner, G. M. (1995). Peer counseling. New Jersey: SLACK Incorporated.

Wang, J., Adair, C., Fick, G., Lai, D., Evans, B., Perry, B. W., Jorm, A., \& Addington, D. (2007). Depression literacy in Alberta: Findings from a general population sample. The Canadian Journal of Psychiatry, 52(7), 442-449. https://doi.org/10.1177/070674370705200706

Xu, Z., Huang, F., Kösters, M., Staiger, T., Becker, T., Thornicroft, G., \& Rüsch, N. (2018). Effectiveness of interventions to promote help-seeking for mental health problems: Systematic review and metaanalysis. Psychological Medicine, 48(16), 2658-2667.

https://doi.org/10.1017/S0033291718001265

Zamani, Z. A., Nasir, R., \& Yusooff, F. (2010). Perceptions towards online counseling among counselors in Malaysia. Procedia-Social and Behavioral Sciences, 5, 585-589.

https://doi.org/10.1016/j.sbspro.2010.07.146

Zhang, Y., \& Ma, Z. F. (2020). Impact of the COVID-19 Pandemic on Mental Health and Quality of Life among Local Residents in Liaoning Province, China: A Cross-Sectional Study. International Journal of Environmental Research and Public Health, 17(7), 2381. https://doi.org/10.3390/ijerph17072381

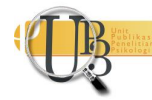

